\title{
EVALUATION OF CORPORATE INTEGRATED REPORTING In SOUTH AfRICA POSt KIng III ReLEASE SOUTH AFRICA - AN EXPLORATORY ENQUIRY
}

\author{
Theophilus S Makiwane+ \\ University of the Witwatersrand \\ 27827458433@vodamail.co.za \\ Nirupa Padia\# \\ University of the Witwatersrand \\ nirupa.padia@wits.ac.za
}

Received: June 2012

Accepted: August 2012

\begin{abstract}
Following the release of the King III report on Corporate Governance for South Africa, which became effective in March 2010, South African companies are expected to embrace the concept of integrated reporting in terms of which they are required to provide details of their strategies, corporate governance, risk management processes, financial performance and sustainability. More importantly, companies need to show how these components of integrated reporting are linked to one another so that stakeholders can make informed decisions about such companies' current performance as well as their ability to create and sustain value in the future. The purpose of this study was to determine whether the level of reporting by South African listed companies has improved since the release of the King III report. It was subsequently found that there have been some progress in this regard, but there is still much room for improvement if the objectives of integrated reporting are to be fully met.
\end{abstract}

Keywords

Integrated reporting, corporate governance, strategies, risk management, sustainability, financial performance, annual reports, King III

+Mr Theophilus S Makiwane was a postgraduate student at the School of Accountancy, University of the Witwatersrand, South Africa.

\#Prof Nirupa Padia is an associate professor and Head of the School of Accountancy, University of the Witwatersrand, South Africa. 


\section{INTRODUCTION}

The collapse of companies in the recent past coupled with the global financial crisis has led many stakeholders to question the ability of the existing financial reporting system to provide relevant information for decision-making (SAIRC Discussion Paper, 2011; Steyn \& De Beer, 2011). The vacuum caused by the inefficiencies of the corporate financial reporting system, which focuses mainly on historical information, has prompted the world to look for a new system that would provide information about companies' future prospects (SAIRC Discussion Paper, 2011). Although in its infancy, in terms of development (Eccles \& Armbrester, 2011), integrated reporting promises to be an ideal system to provide the information needed for decisionmaking.

Integrated reporting is a new concept not only in South Africa but all over the world. In the King Report on Governance for South Africa 2009 (King III), it is defined as an integrated representation of the company's performance in terms of both its finances and its sustainability (IOD, 2009). In terms of this definition, companies are encouraged to assess their performance holistically in that they have to consider various aspects that are essential to the success of their businesses. These aspects include: (1) the adoption of effective strategies; (2) the implementation of good corporate governance practices; (3) the application of effective risk management processes; (4) the assessment of the company's financial performance; and (5) the promotion of sustainability, which includes addressing economic, social and environmental issues (IOD, 2009; SAIRC Discussion Paper, 2011).

In South Africa, integrated reporting is covered in detail by King III (IOD, 2009), which dedicates a separate chapter to this topic. Given the importance of this concept, the South African Integrated Reporting Committee (SAIRC) was formed in May 2010 (Accountancy SA, December 2011) to look specifically at the integrated reporting issues at length. This culminated in the publication of the Discussion Paper on Integrated Reporting in January 2011 (SAIRC Discussion Paper, 2011). On the international front, the International Integrated Reporting Committee (IIRC) was formed. This committee engaged in an extensive consultative process with different organisations and individuals around the world including the United Nations, the Global Reporting Initiative (GRI), accountants, lawyers, and environmentalists (IIRC Discussion Paper, 2011).

While integrated reporting is a new concept globally, South Africa is one of the countries that has taken the lead in terms of urging its companies to embrace the concept in their reporting (South Africa. Info, January 2011). South African listed companies are required, in terms of the Johannesburg Stock Exchange listing requirements (JSE, 2011), to comply with the King III (IOD, 2009) guidelines with effect from 1 March 2010. In the event that they fail to comply with the guidelines, companies need to provide reasons for failing to do so (JSE, 2011). In many other countries, however, there are no mandatory requirements other than a recommendation that companies operating in such countries can follow the guidelines provided in the IIRC Discussion Paper (2011). These guidelines are currently in the development stage and the IIRC hopes to issue an Exposure Draft in 2012 after it has solicited the views of various organisations and the public (IIRC Discussion Paper, 2011).

Since, in terms of the JSE listing requirements (JSE, 2011), South African listed companies are required to adopt integrated reporting, the purpose of this study is to evaluate the extent to which the level of reporting by the South African listed companies has improved since the 
emphasis of adopting integrated reporting in King III (IOD, 2009), which came into effect on 1 March 2010.

The remainder of this article is organised as follows. Section 2 reviews the literature relevant to integrated reporting and its components. Section 3 deals with the research methodology adopted in this study. Section 4 provides the research results. Section 5 concludes the discussion and makes recommendations for future research.

\section{LITERATURE REVIEW}

In this section, literature relating to the components of integrated reporting, namely, financial performance, corporate governance, strategy, risk management and sustainability, is reviewed. However, this section begins with an overview of integrated reporting in order to provide a perspective for the entire paper.

\subsection{Integrated reporting}

In the past, companies tended to produce various reports, including sustainability reports, containing information that diverged greatly from the economic realities of their business and which were prepared in a manner that made it difficult to ascertain any business value (SAIRC Discussion Paper, 2011; Carte, 2011). This was due to the fact that the reports were prepared in a disjointed manner; the information they contained could not be connected with the information presented in the other parts of the report, such as that on financial performance (SAIRC Discussion Paper, 2011).

On the other hand, integrated reporting, which builds on the guidelines of the Management Commentary, a Practice Statement issued by the International Accounting Standards Board in December 2010 (IASB, 2010), provides management with a platform for reporting on their financial and non-financial performance in a single report (Eccles \& Armbrester, 2011) by providing an overview of their operations, as well as showing the connection between the various concepts of integrated reporting, namely, strategies, corporate governance, risks, financial performance and sustainability (IOD, 2009; SAIRC Discussion Paper, 2011; IIRC Discussion Paper, 2011). Such a connection enables stakeholders to assess the companies' performance holistically in terms of their ability to create and sustain value in the short, medium and long term (SAIRC Discussion Paper, 2011; South Africa. Info, January 2011).

Transparency, accountability and leadership are at the heart of integrated reporting and form the important pillars of corporate governance (SAIRC Discussion Paper, 2011), as discussed in section 2.3. Driven by these values, companies will be able to select material and relevant information that will be of interest to the stakeholders. To achieve transparency and accountability in their reporting, King III (IOD, 2009) recommends that companies should strike a balance by reporting both positive and negative information rather than merely providing a one-sided view. Reporting in this manner would make it easier for management and stakeholders to identify those risks that are a threat to the company and the risks that can be turned into opportunities (IOD, 2009). In the selection process, companies should be guided by the principle of "substance over form" to ensure that information is selected on the basis of its economic merits rather than its legal form (IOD, 2009). 


\subsection{Financial performance}

In pursuing the concept of integrated reporting, a company should not lose sight of the primary objective of conducting business. Unlike in the past, the primary objective in the twenty-first century is to make sustainable profits within a threefold context of finance, society and the environment $(I 0 D, 2009)$ for the wellbeing of its shareholders, employees and other stakeholders.

This implies that the presentation of a company's financial performance alone is no longer adequate (IIRC Discussion Paper, 2011; IOD, 2009), given that companies now cater for a wide range of stakeholders with different interests. Financial performance therefore needs to be supplemented with other information to enable the stakeholders to obtain a holistic view of a company's performance and to assess its ability to create and sustain value.

\subsection{Corporate governance}

The concept of corporate governance is deeply rooted in agency theory, that is, the separation of ownership from control of the company (Jensen \& Meckling, 1976). In terms of agency theory, the owners (principals) of the company do not have the power to control the company, as such control has been shifted to the managers (agents). The problem that arises is that managers may abuse their powers by deciding to release or withhold information at their own discretion (Rossouw, Van der Walt \& Malan, 2002; Jensen and Meckling, 1976). Corporate governance thus becomes an essential tool for bridging that gap, thereby ensuring that managers provide owners and other stakeholders with relevant information (Rossouw et al., 2002).

Corporate governance is based on the values of transparency, accountability, responsibility and fairness (Shkolnikov \& Wilson, 2009; IOD, 2009; GRI, 2011; Gray, 2001). These values require managers to provide material and relevant information that is of interest to the company's stakeholders (IOD, 2009; GRI, 2011). Once the company decides to adopt the values, it should ensure that they are entrenched across all its operations (IOD, 2009). Transparency requires companies to provide relevant information in a clear and concise manner so as to enable stakeholders to make an informed analysis of their performance (IOD, 2009; Gray, 2001). Accountability requires managers to justify their decisions and actions to the stakeholders (IOD, 2009). With regard to responsibility, managers are required to assume responsibility for the assets and actions of the company (I0D, 2009). In demonstrating fairness, companies are expected to treat all stakeholders equally, including minority shareholders (Shkolnikov \& Wilson, 2009).

Corporate governance is an important pillar not only of companies but also of government institutions given the role that governments play in creating job opportunities and in paving the way for economic growth (Shkolnikov \& Wilson, 2009). However, prior research has shown that governments, especially in the emerging markets, tend to lag behind the developed countries in terms of good corporate governance principles (Shkolnikov \& Wilson, 2009). Emerging markets are often plagued by corruption, bribery, political patronage and officials who want to advance their own interests at the expense of social development (Shkolnikov \& Wilson, 2009). Corruption and other bad governance practices by governments and companies have negative consequences for the economy, and often give rise to poverty in their countries, as the money earmarked for projects, job creation and development ends up in the hands of corrupt individuals (Shkolnikov \& Wilson, 2009). 
In 1992, South Africa made its first real attempt to tackle corporate governance problems with the formation of the King Committee (chaired by Mervyn King) by the Institute of Directors of Southern Africa (IOD, 1994). This committee followed in the footsteps of the Cadbury Committee set up in the United Kingdom to look into similar corporate governance issues. However, the mandate of the King Committee was broader than that of the Cadbury Committee in that it also dealt with a wide range of issues peculiar to South Africa, such as the transformation and affirmative action necessitated by changes in the South African political system.

After an extensive consultative process with various organisations and individuals, the King Committee released its first report on corporate governance for South Africa in November 1994 (King I). Following changes to the labour laws, accounting standards and other business dimensions subsequent to King I, a second set of guidelines was issued by the King Committee in March 2002 (King II). Later, a third set was published in September 2009 and became effective in March 2010 (King III). King III (IOD, 2009) came into being following amendments to the Companies Act of 2008 relating to audit committees, as well as, and more importantly, to address new issues such as integrated reporting and to provide more guidance on issues relating to information technology, compliance and stakeholder relationships.

King III (IOD, 2009) deals extensively with the following components of corporate governance: (1) Ethical Leadership and Corporate Citizenship; (2) Boards and Directors; (3) Audit Committees; (4) the Governance of Risk; (5) the Governance of Information Technology; (6) Compliance with Laws, Rules, Codes and Standards; (7) Internal Audit; (8) Governing Stakeholder Relationships; and (9) Integrated Reporting and Disclosure. Adoption of these components by companies in the course of their business would guarantee them viability and sustainability in the future.

\subsection{Strategies}

To ensure the sustainability of their business in the future, companies need to adopt sound strategies (I0D, 2009). A strategy is defined by the Oxford Advanced Learner's Dictionary (2000) as a plan that is intended to achieve a particular purpose. To be able to achieve a purpose requires a company to know where it is going in terms of its short-, medium- and long-term plans (Hay \& Williamson, 1997). Like a tower with many coherent levels, a strategy should show similar coherence and should be an integral part of a company's day-to-day activities (Hay \& Williamson, 1997).

The effective implementation of strategies requires strong and effective leadership (I0D, 2009). Companies often benefit from strong leadership that is not afraid to make choices and decisions (Porter, 1996). It is a pity, though, that, in some companies, leadership has degenerated into performing activities that promote operational effectiveness only, rather than formulating effective strategies (Porter, 1996).

\subsection{Risk management}

Risk management is an essential component of corporate governance (Bhimani, 2009; Sarens, De Beelde \& Everaert, 2009) and is aimed at assisting companies to identify threats to their business for the purpose of taking appropriate action before any damage is caused. The definition of risk as the "taking of risk for a reward" (IOD, 2009) is a constant reminder to companies to understand that the act of conducting business implies that risks cannot be entirely eliminated, but efforts should be made to identify those risks, which can then be turned 
into opportunities (Olsson, 2007). If viewed in this way, it might help to do away with the tendency among many companies to view risk management mainly from one perspective - as a tool to eliminate the threats facing their business (I0D, 2009).

Risk management entails the identification, analysis, mitigation, monitoring and reporting of risk (Van Wyk, Bowen \& Akintoye, 2008). It also entails risk evaluation and quantification where this is practicable $(I 0 D, 2009)$. Risk management cannot be done haphazardly but requires coordinated efforts on the part of various functions in the organisation. A risk management policy should therefore set the tone for risk management and should also indicate how risk management supports the company's strategy (I0D, 2009).

Monitoring and evaluation of the risk management processes on a regular basis is an important aspect in determining whether or not the company is on course to achieve its objectives (IOD, 2009; McCarty \& Power, 2000). While risk management is the responsibility of the board, King III $(I 0 D, 2009)$ recommends the delegation of this function to a risk committee comprising both executive and non-executive directors. The involvement of executive directors is important given their intimate knowledge of the business.

\subsection{Sustainability considerations}

Sustainability reporting is not a new concept but has its background in the 1970s (Kolk, 2005). In those days, reporting was limited, as companies tended to focus on the social issues instead of also addressing economic and environmental issues (Kolk, 2005). This is supported by surveys showing that, by the late 1970 s, $90 \%$ of Fortune 500 companies reported on social issues in their annual reports (Kolk, 2005). Although social issues received attention, there was little reporting on these issues, with their coverage often being limited to less than a page (Kolk, 2005).

In the early 1980s, social reporting lost momentum following the global recession and the resulting high rates of unemployment (Kolk, 2005; Gray, 2001). This led to a shift in focus from social reporting to economic issues. It was not until the late 1980s and early 1990s that companies began to report on social issues again (Gray, 2001), this time including environmental issues. According to Kolk (2005), this second wave of reporting was largely due to pressure from non-governmental organisations which required companies to cover both social and environmental issues in their reports.

Following the Rio Declaration (UN Agenda 21, 1992) adopted by many governments at the United Nations summit held in Brazil in 1992, the international community showed its commitment to addressing sustainability issues in different ways. For example, in 1997 the Global Reporting Initiative (GRI, 2011) issued guidelines on sustainability (Nazari, 2009; Labuschagne, Brent \& Van Erck, 2004); this was followed later by the release of the UN Global Compact in 2000. These two documents complement one another. The GRI (2011), in particular, deals extensively with guidelines for reporting on sustainability issues based on the three themes, namely, economic, environmental and economic issues. The GRI (2011) gained popularity and was widely quoted by many European and American companies in their reporting.

Although the sustainability guidelines published by the GRI (2011) and the UN Global Compact (2000) are useful, a large number of non-governmental organisations and the investor community prefer these guidelines to be regulated, as, in their view, companies purporting to follow the guidelines often pick and choose only those issues that favour them instead of addressing a wide range of stakeholder needs (Ligteringen \& Zadek, 2002). Mandatory reporting is further supported by Doane (2002) and Adams and Zutshi (2004), who believe that it will allow 
the markets to operate more effectively by ensuring that all stakeholders receive relevant and transparent information.

Sustainability reporting has also gained momentum in South Africa following the release of the corporate governance guidelines by the King Committee, that is, King II in 2002 and King III in 2009 (IOD, 2002; IOD, 2009). King III (IOD, 2009) extended the concept of sustainability reporting to incorporate integrated reporting, which, in essence, requires companies to report on sustainability issues, that is, economic, social and environmental issues, and, at the same time, to show their link to the company's strategy, corporate governance, risks and financial performance.

\section{RESEARCH METHODOLOGY}

\subsection{Nature of the study}

This study is regarded as a comparative study, as it compares the level of reporting, as far as integrated reporting is concerned, by South African listed companies in the current year $(2010 / 2011)$ to that of the base year (2009) to determine whether the level of reporting has improved since King III became effective in March 2010 (I0D, 2009).

The source of data for this research is the annual reports published by the listed companies for the current year as well as the base year. These annual reports have been extracted from the McGregor database, a reputable database used by a wide range of individuals and organisations. The annual reports were the only source of data used. Accordingly, research indicators were applied to these reports to determine the extent to which the level of reporting has improved in the current year compared to the base year.

\subsection{Research approach}

A pilot study was initially undertaken to facilitate the approach to be adopted in the actual study. The results of the pilot study revealed some important aspects which were taken into account in the actual study. Firstly, there were no significant differences in terms of reporting by companies during the period 2006 to 2009. These results were in line with the researcher's expectations, confirming compliance by companies only with the King II guidelines (IOD, 2002) during these periods. Since similar patterns of reporting were expected for the periods during which King II was in force, 2009 has been used as a representative period for all the periods from 2002 to 2009 and is regarded as the base year.

On the other hand, although King III became effective in March 2010, it was first released in September 2009, thus making it possible for companies to start implementing its guidelines as early as 2010 . Some companies were proactive in this regard in the sense that, even though they were not obliged to comply with the King III guidelines because of their financial year cycles, they nevertheless started incorporating the King III recommendations into their annual reports for 2010. Part of the reason for early compliance was attributed to the fact that it would be in the best interests of their businesses to do so. It is for this reason that this study took the view that, despite the varying financial cycles of companies, companies were nevertheless expected to comply with the King III recommendations from the beginning of 2010. While this approach might be unfair to other companies, it was considered an ideal approach in this study for both consistency and comparability purposes. 
Another aspect considered in this study was the fact that companies may have issued either 2010 or 2011 annual reports by the cut-off date of 31 December 2011, which was chosen for the purposes of this research. The date on which the individual reports were released was ascertained and preference was given to the 2011 annual reports, as these were expected to have incorporated more King III recommendations than the 2010 annual reports. In cases where companies had no 2011 report, the 2010 annual reports were used. In both cases, 2010/2011 is regarded as the year to be compared to 2009 (the base year) for the purposes of determining any improvement in the level of reporting.

\subsection{Population, sample selection and research indicators}

In September 2011, the McGregor database consisted of 401 listed companies, broken down into various industries; these made up the population of this study. Subsequently, a sample size of 92 companies was identified for the purposes of this research; this took into account the fact that the analysis was extended to the entire population and the individual sectors making up the population.

A total of 111 research indicators were selected mainly from King III (IOD, 2009) and the GRI (2011). However, there were a few research indicators that were selected based on the researchers' judgement. Given the varying strengths of King III (IOD, 2009) and the GRI (2011), the key research indicators on corporate governance, risk management and strategy were selected from the King III report, whereas those for sustainability, consisting of economic, social and environmental elements, were selected from the GRI (2011). A list of the research indicators used in the study will be made available by the authors on request.

With regard to financial performance, no attempt was made to include the financial performance indicators in the same way as indicators for the other concepts of integrated reporting. This decision was based on the fact that companies use different financial indicators and the selection of indicators used by one group of companies may not necessarily address the financial performance of another group of companies.

Each research indicator used was allocated a score of " 1 " to " 5 " with the following meanings: "l" meaning "non-compliance" - the equivalent of $0 \%$; "2" meaning "little detail provided" ranging between $0 \%$ and $25 \%$ (poor/average); "3" meaning "some detail provided" - ranging between $25 \%$ and $50 \%$ (satisfactory); "4" meaning "more detail provided" - ranging between $50 \%$ and $75 \%$ (good); and " 5 " meaning "much detail provided" - ranging between $75 \%$ and $100 \%$ (very good/excellent). The allocation of scores was first done on the companies that formed part of the pilot study to determine their effectiveness (see section 3.2). This exercise proved to be instrumental in refining the scores. While subjectivity could not be entirely eliminated, in order to achieve the desired results this research relied on the consistency of the allocated scores.

\subsection{Data analysis and interpretation}

\subsubsection{Statistical methods used}

This research did not use parametric statistics owing to the basic categorical nature and the non-normality of data when treating them as numeric scale data to calculate mean score values. Instead, descriptive statistics and non-parametric methods were used to analyse the data. This study used the non-parametric Spearman's rho to determine whether there is any 
correlation between the scores for the current year and the scores for the base year for each indicator. High correlation between the years is an indication of little improvement in reporting in the current year when compared to the base year. On the other hand, low correlation is an indication of some improvement in the current year.

Besides the Spearman's rho correlation, this study also made use of the mean scores and the mean score differences to determine whether, on average, companies demonstrated any improvement in the level of reporting. Unlike Spearman's rho correlation, the mean scores and the mean score differences are used to determine whether a change in the pattern of reporting is due to an improvement or not. A higher mean score in the current year than in the base year indicates, on average, an improvement in the level of reporting by companies in the current year. The opposite is true for a lower mean score in the current year when compared to the base year. The magnitude of the mean score differences is used to quantify the improvement or deterioration. Equal means in both the base year and the current year is an indication that, on average, the companies did not demonstrate any change in their level of reporting.

\subsubsection{Harmonisation of information}

Integrated reporting requires a company to present information about its strategies, corporate governance, risk assessment, financial performance and sustainability in a manner that will allow stakeholders to draw a link between these integrated reporting concepts (I0D, 2009; SAIRC Discussion Paper, 2011). In other words, this information should be harmonised from the beginning of the report right through to the end of that report.

It is common for companies to address the concepts of integrated reporting in the chairman's, chief executive's, financial director's or other executives' reports. Irrespective of how the information is presented, the company should ensure that the commentary by directors complements the information presented in the other parts of the report. The harmonisation of information is a critical aspect of integrated reporting and this is the essence of this study. It is for this reason that some research indicators were selected to deal specifically with the tone and harmonisation of information in the companies' annual reports.

\section{RESEARCH RESULTS}

\subsection{Comparison between the mean scores of the current year and the base year per individual main categories}

FIGURE 1 compares, for each category of indicators, the mean scores of the current year (2010/2011) and those of the base year (2009) in order to investigate whether any improvement in the level of reporting has been achieved in the current year.

Given the large number of indicators in each main category, presenting individual indicators could make the interpretation difficult especially if they are all presented graphically. Instead, it was decided to show the mean scores of the main categories, which were created by calculating the mean scores of the set of indicators that falls under each category. The mean scores for all categories in FIGURE 1, overall, show companies improved in terms of the level of their reporting in the current year compared to the base year. 


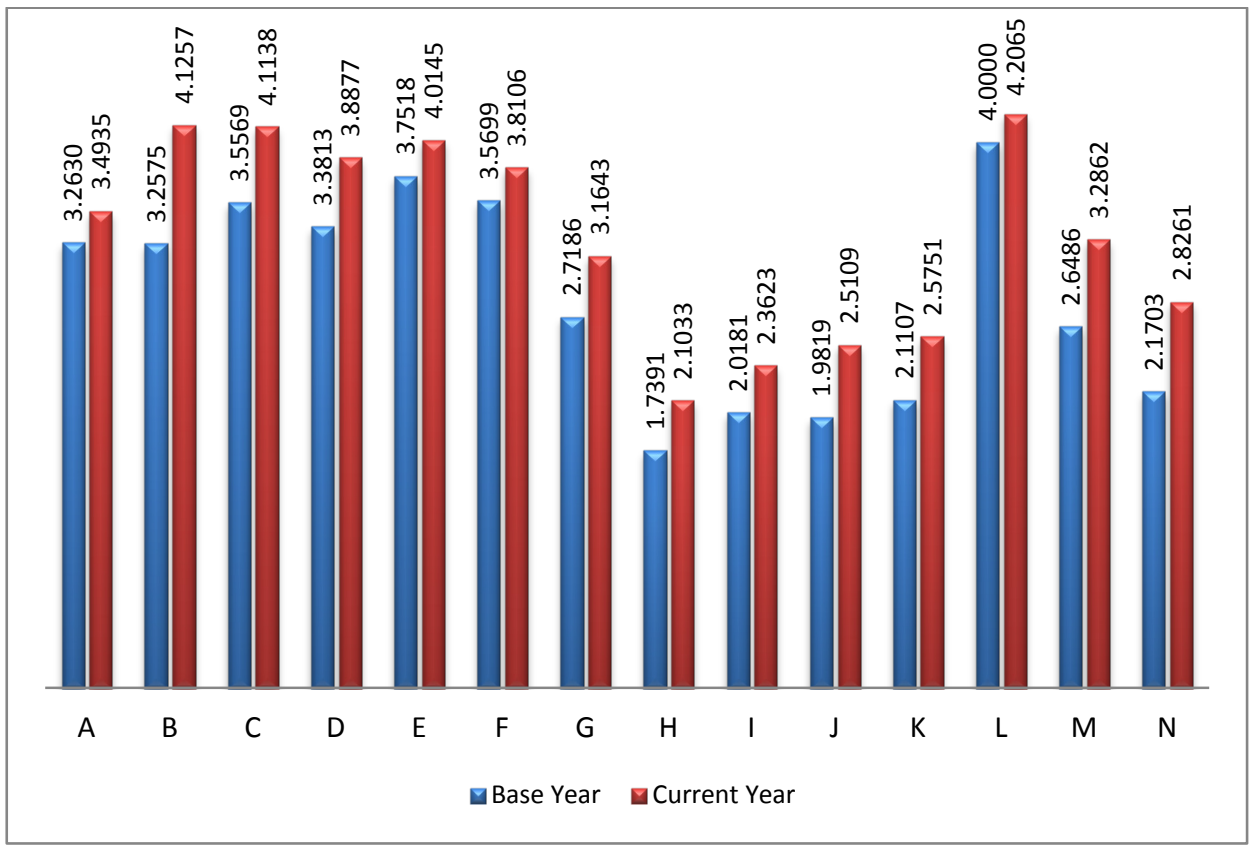

FIGURE 1: Comparison between the mean scores per category

Source: Authors'analysis

Legend

A - Ethical leadership and corporate citizenship; B - Boards and directors; C - Audit committee; D - Risk management committee; $\varepsilon$ - Remuneration committee; F - Nomination committee; G - Internal audit function; H - Governance of information technology; I - Compliance with laws, rules, codes and standards; J - Governing stakeholder relationships; $\mathrm{K}$ Integrated reporting; L - Economic sustainability; $M$ - Social sustainability; $N$ - Environmental sustainability

\subsection{Comparison of the "integrated annual reports" and the "annual reports"}

Out of 92 companies, only 35 (representing 38\%) issued reports entitled "integrated annual reports" in the current year, while the remaining 57 companies (representing 62\%) issued reports titled "annual reports". This study expected companies with "integrated annual reports" to perform better in terms of the level of their reporting in the current year than those with the "annual reports".

The graph in FIGURE 2 confirms expectations that, overall, companies with the "integrated annual reports" performed better than those with "annual reports" in all main categories. The graph further illustrates that 10 out of 14 categories show significant improvement in the level of reporting by companies that issued "integrated annual reports". Using the mean score differences, such significant improvements have been noted in the case of (1) Ethical Leadership and Corporate Citizenship; (2) Risk Management; (3) Nomination Committee; (4) Internal Audit Function; (5) Governance of Information Technology; (6) Governing Stakeholder Relationships; (7) Integrated Reporting; (8) Economic Sustainability; (9) Social Sustainability; and (10) Environmental Sustainability. 


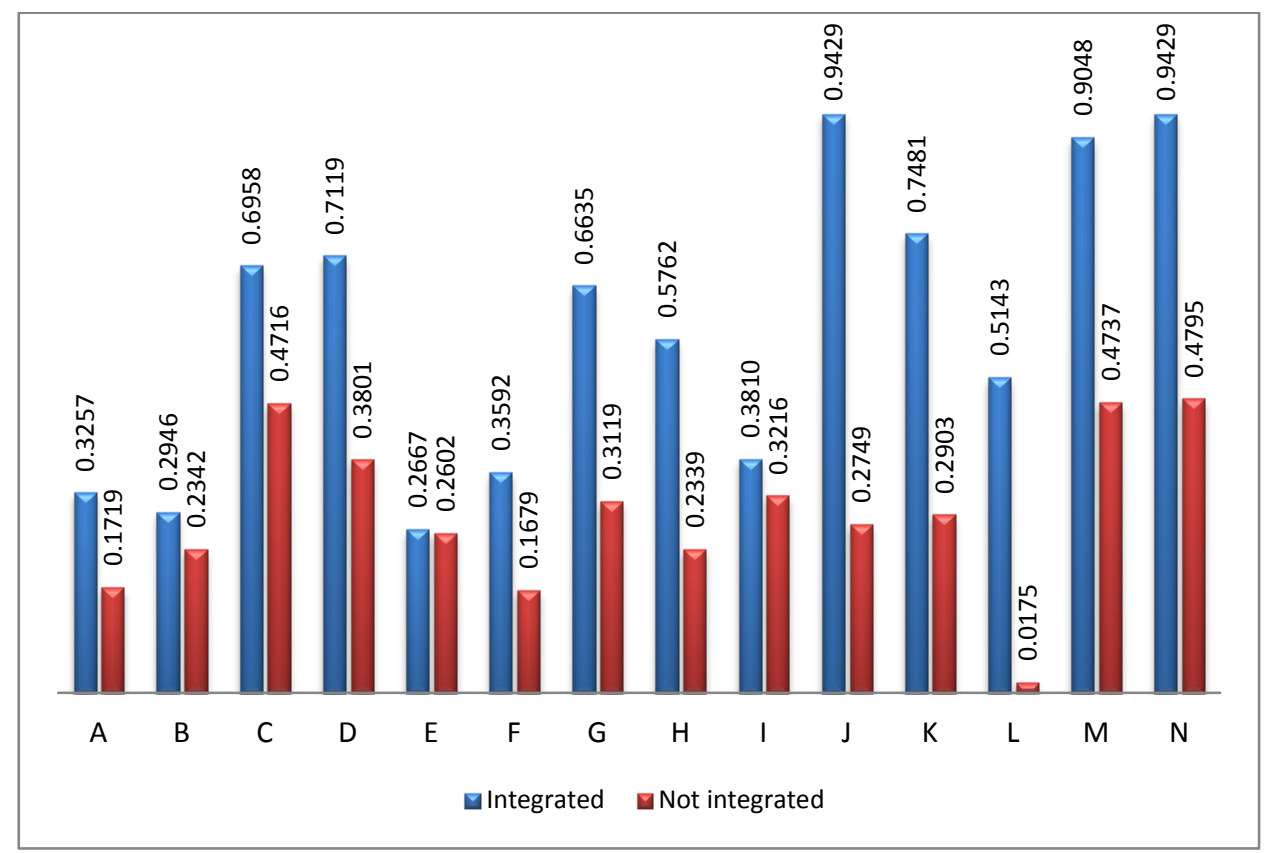

FIGURE 2: Comparison between reports

\section{Source: Authors'analysis}

Legend

A - Ethical leadership and corporate citizenship; B - Boards and directors; C - Audit committee; D - Risk management committee; $\varepsilon$ - Remuneration committee; $F$ - Nomination committee; $G$ - Internal audit function; $\mathrm{H}$ - Governance of information technology; I - Compliance with laws, rules, codes and standards; J - Governing stakeholder relationships; $\mathrm{K}$ - Integrated reporting; $\mathrm{L}$ - Economic sustainability; $M$ - Social sustainability; $\mathrm{N}$ Environmental sustainability

These results can be interpreted as showing that companies that have published "integrated annual reports" have taken a step in the right direction in terms of complying with the King III guidelines (IOD, 2009) and the JSE listing requirements (JSE, 2011). The results also confirm that those companies that did not release "integrated annual reports" are already lagging behind those that did, and stand to lose out in terms of the benefits associated with integrated reporting. Such benefits include (1) the ability to attract investors to their businesses; and (2) increasing public confidence which would guarantee them success in the future.

\subsection{Indicators showing significant improvement in the level of reporting}

TABLE 1 illustrates those individual indicators for which the coefficients of correlation between the current year and the base year show significant improvement in the reporting patterns. All the mean differences are positive, implying much improved performance by companies in terms of the level of reporting against each indicator in the current year compared to the base year. It should be noted that such significant improvement in the level of reporting has been demonstrated for just a few of the indicators (shown in TABLE l) under the three main 
categories, namely, Boards and Directors, Audit Committee and Governance of Information Technology (IT).

TABLE 1: Indicators showing significant improvement

\begin{tabular}{|c|c|c|c|}
\hline \# & Indicator & $\begin{array}{l}\text { Spearman } \\
\text { correlation } \\
\text { coefficient }\end{array}$ & $\begin{array}{l}\text { Mean } \\
\text { difference }\end{array}$ \\
\hline A & Boards and Directors & & \\
\hline 1 & CFO is a board member & 0.318 & 0.348 \\
\hline 2 & Remuneration of the three most highly paid employees is disclosed & 0.370 & 0.648 \\
\hline B & Audit Committee & & \\
\hline 3 & Meets at least twice a year & 0.304 & 0.109 \\
\hline 4 & Oversees the preparation of the integrated report & 0.199 & 1.033 \\
\hline 5 & Applies a combined assurance model on risk, internal audit and others & 0.345 & 1.196 \\
\hline 6 & Reports to the board how it carried out its responsibilities & 0.251 & 1.315 \\
\hline C & Governance of Information Technology & & \\
\hline 7 & Board monitors and evaluates significant IT investments and expenditure & 0.315 & 0.207 \\
\hline 8 & Board ensures that IT complies with IT laws, rules, codes and standards & 0.307 & 0.283 \\
\hline 9 & Risk committee/other structure oversees overall risk implications of IT & 0.313 & 0.435 \\
\hline 10 & $\begin{array}{l}\text { Audit committee/other structure oversees financial risk implications of } \\
\text { IT }\end{array}$ & 0.364 & 0.533 \\
\hline
\end{tabular}

Source: Authors' analysis

Of the 10 indicators shown in TABLE 1, eight are new indicators identified by King III (IOD, 2009), namely, (1) remuneration of the three most highly paid employees is disclosed; (2) oversees the preparation of the integrated report; (3) applies a combined assurance model on risk, internal audit and others; (4) reports to the board how it carried out its responsibilities; (5) board monitors and evaluates significant IT investments and expenditure; (6) board ensures that IT complies with IT laws, rules, codes and standards; (7) risk committee/other structure oversees overall risk implications of IT; and (8) audit committee/other structure oversees financial risk implications of IT. The remaining two indicators, that is, (1) CFO is a board member; and (2) audit committee meets at least twice a year, are part of the King II guidelines (IOD, 2002).

The eight new indicators indicate companies' level of commitment to start complying with the new King III recommendations (IOD, 2009). This commitment has, in particular, been demonstrated by companies in terms of information technology, which is an important tool for helping companies to remain competitive. Although the other indicators did not show any significant improvement, it is nevertheless interesting to note that the South African listed companies have taken steps to improve the level of their reporting. 


\subsection{Level of reporting by existing indicators as per the King II report}

The objective of the analysis in this section was to determine whether the level of reporting by companies had improved in the current year relative to the base year despite the fact that the indicators had been in existence since the publication of the King II report in 2002 (IOD, 2002). Under normal circumstances, there should not be much difference in the level of reporting in the current year relative to the base year given that the same set of indicators was applied to both years.

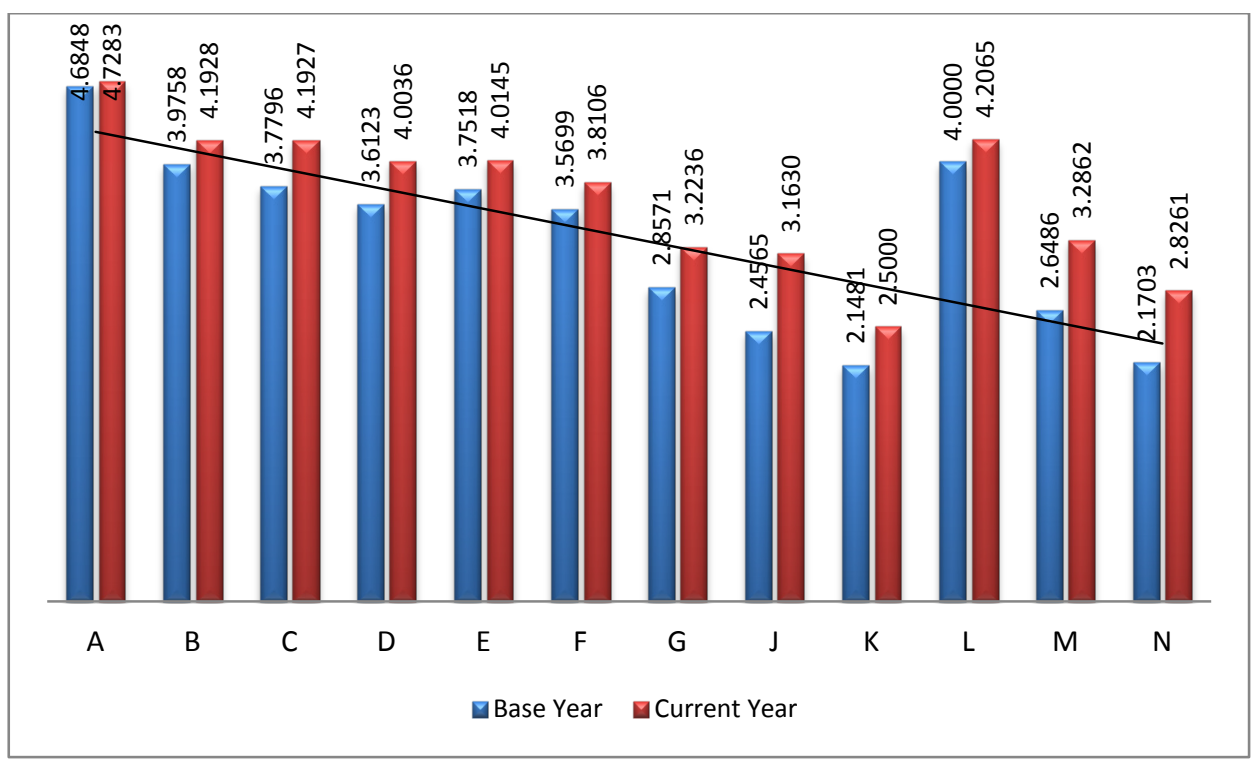

FIGURE 3: Level of reporting by existing indicators

Source: Authors'analysis

Legend

A - Ethical leadership and corporate citizenship; B - Boards and directors; C - Audit committee; D - Risk management committee; $\varepsilon$ - Remuneration committee; $F$ - Nomination committee; $G$ - Internal audit function; $J$ - Governing stakeholder relationships; $K$ - Integrated reporting; L - Economic sustainability; $M$ - Social sustainability; $\mathrm{N}-$ Environmental sustainability

Surprisingly, the results in FIGURE 3 show an improvement in the level of reporting in the current year compared to the base year. This is an important finding which confirms the change in attitude by companies subsequent to the publication of King III (IOD, 2009). This change in attitude is also attributable to changes concerning the role of audit committees, which were made to the Companies Act (Companies Act, 2008). In addition, the JSE listing requirements (JSE, 2011) require companies to comply with the King III guidelines or to provide reasons for failing to do so.

\subsection{Level of reporting by new indicators as per the King III report}

The purpose of introducing the new indicators is to determine whether there is any improvement in the level of reporting in the current year compared to the base years despite the fact that the new indicators were introduced only in the current year. 
Using the new indicators from King III (IOD, 2009), the results in FIGURE 4 show improvement in the level of reporting in the current year compared to the base year. At first glance, these results might be confusing, as one would have expected non-compliance by companies in the base year, given that the new indicators came into being only after the release of King III, which became effective in March 2010.

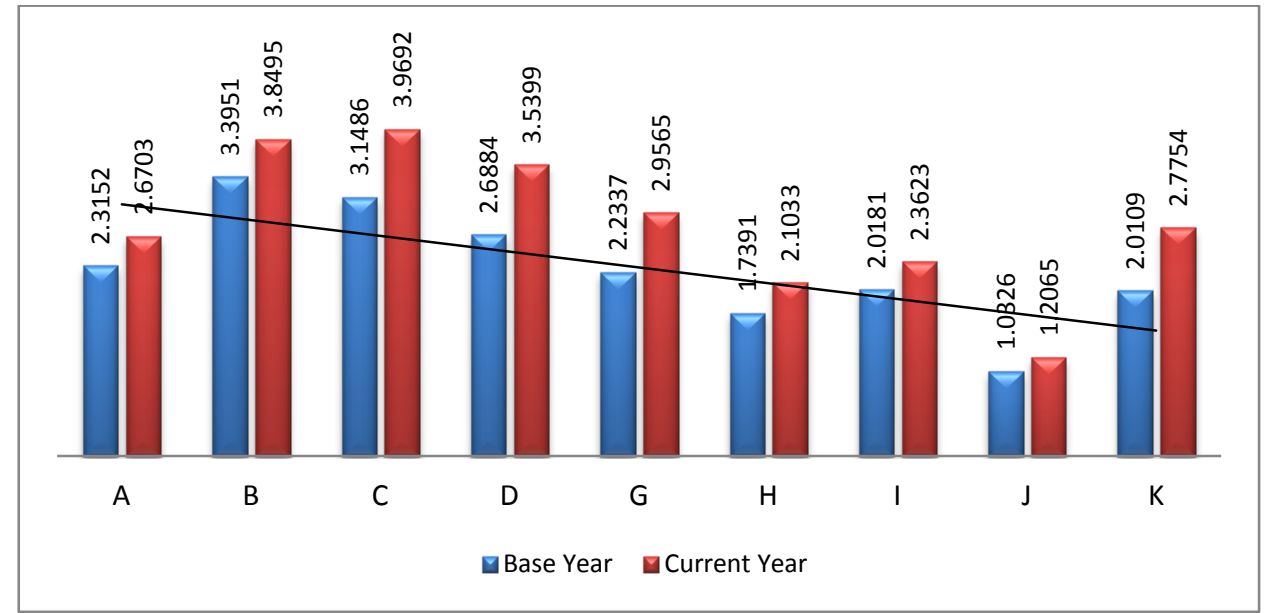

FIGURE 4: Level of reporting by new indicators

Source: Authors'analysis

Legend

A - Ethical leadership and corporate citizenship; B - Boards and directors; C - Audit committee; D - Risk management committee; $\mathrm{G}$ - Internal audit function; $\mathrm{H}$ - Governance of information technology; I - Compliance with laws, rules, codes and standards; J - Governing stakeholder relationships; K - Integrated reporting

However, the results lead one to believe that the King Committee might have been involved in an extensive consultative process with companies to determine the trends in reporting subsequent to King II (IOD, 2002). Accordingly, this process might have resulted in some of the good practices by companies being incorporated into the King III guidelines (IOD, 2009). Therefore, in some companies, the King III guidelines are a new phenomenon, whereas in others such guidelines are an extension of the existing practices in their operations. This would then explain why the new guidelines appear to have been present in the base year.

\subsection{Harmonisation between components of integrated reporting}

FIGURE 5(a) illustrates how companies have performed in terms of reporting on the components of integrated reporting, based on comments by the chairmen, chief executives and other executives within companies.

The graph shows that, on the scale of " 1 " to " 5 ", where " 1 " means "non-compliance" and " 5 " means "much compliance", companies improved significantly in covering integrating reporting issues in the current year relative to the base year, since top executives provided much commentary. 


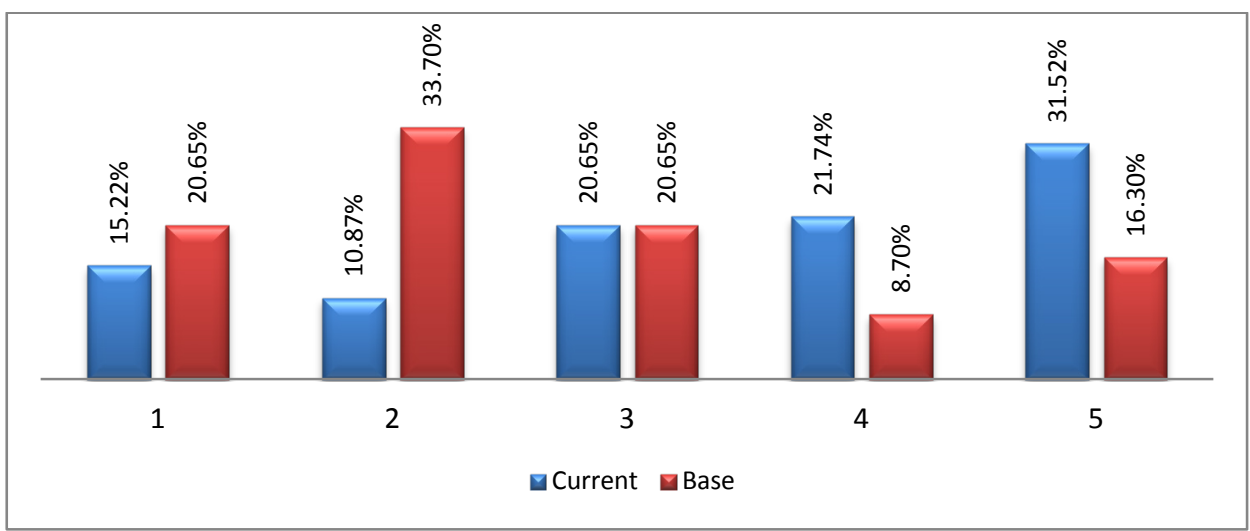

FIGURE 5(a): Tone on integrated reporting components in introduction, chairman's and CEO's commentary

\section{Source: Authors'analysis}

Legend

1 - Non-compliance; 2 - Little detail provided, 3 -Some detail provided; 4 -More detail provided; 5 -Much detail provided

FIGURE 5(b), on the other hand, illustrates how companies managed to show connections between the integrated reporting components, namely, strategy, risk, corporate governance, financial performance and sustainability.

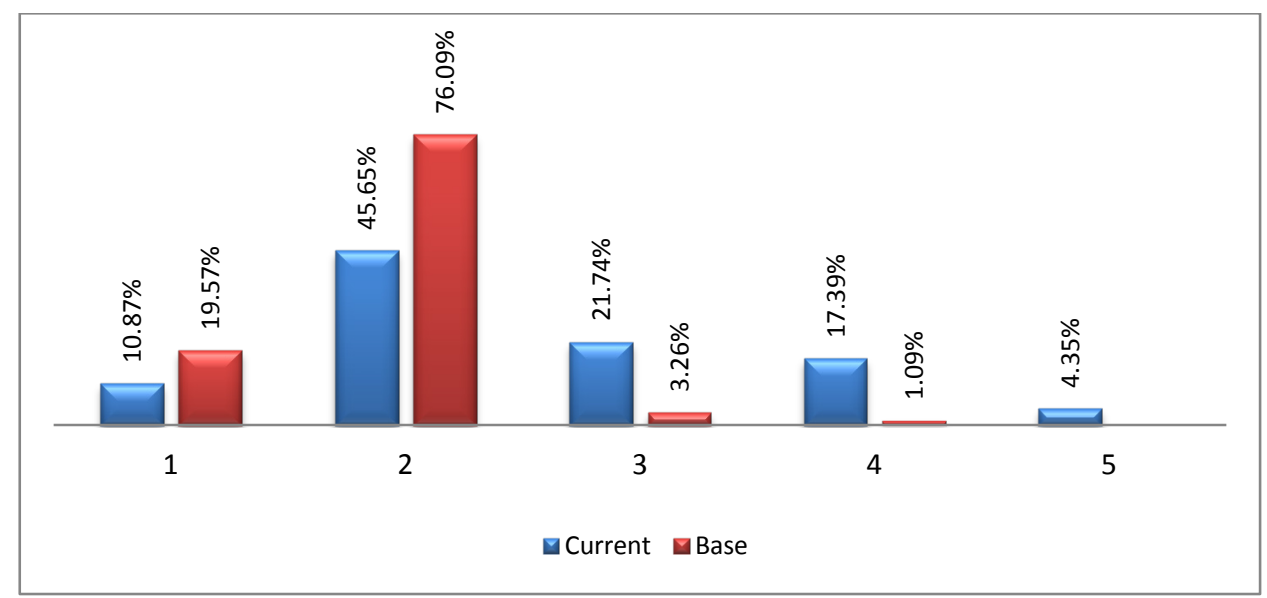

\section{FIGURE 5(b): Harmonisation of integrated reporting components}

Source: Authors'analysis

Legend

1 - Non-compliance; 2 - Little detail provided, 3 -Some detail provided; 4 -More detail provided; 5 -Much detail provided 
On the scale of "l" to " 5 ", where "l" means "non-compliance" and " 5 " means "much compliance", FIGURE 5(b) shows much improvement in terms of harmonisation in the components of integrated reporting in the current year relative to the base year.

\section{CONCLUSION}

The purpose of this research was to determine whether the level of reporting by South African listed companies has improved since the introduction of King III in March 2010 (IOD, 2009). This report encourages companies to embrace the concept of integrated reporting in terms of which they are expected to report on their strategies, corporate governance, risk assessment, financial performance and sustainability dimensions, and to show how these components are connected to one another so as to enable stakeholders to assess companies' performance holistically in terms of their ability to create and sustain value (IOD, 2009, SAIRC Discussion Paper, 2011).

This study acknowledges the importance of adopting, as the cornerstone of good corporate governance practices, the values of transparency, accountability, responsibility and fairness in all spheres of business operations and across all government institutions with the purpose of restoring faith in the capital markets (IOD, 2009). Once adopted, these values will help to encourage managers to provide relevant information of interest to stakeholders. In addition, in order to ensure their future success companies should address economic, social and environmental impacts (IOD, 2009; GRI, 2011). According to the United Nations, companies failing to address these sustainability considerations have no future in the twenty-first century, as they are likely to lose favour in the societies in which they operate (GRI, 2011; UN Global Compact, 2000).

Overall, the results confirmed improvement in the level of reporting by South African listed companies in the current year relative to the base year. In some instances, this improvement was significant, especially when comparisons were made between those companies that issued integrated annual reports and those that did not. The results showed that companies with integrated annual reports made more effort in terms of improving the level of their reporting than those without integrated annual reports. The results further confirmed that companies without integrated annual reports were already lagging behind those with such reports and might lose out in terms of competitiveness.

Significant improvement was also noted in the case of ten individual indicators grouped under Boards and Directors, Audit Committees and Information Technology. With regard to Audit Committees, these results were expected to confirm compliance by companies with the King III recommendations (IOD, 2009) as well as the Companies Act (Companies Act, 2008). In the case of Information Technology, the results signified the importance of companies implementing appropriate strategies for information systems in order to enable them to gain competitive advantage over their rivals.

In line with the International Integrated Committee's (IIRC) thinking (IIRC Discussion Paper, 2011), this study acknowledges that integrated reporting is a new concept not only in South Africa but internationally. It will therefore take a considerable time before the intended objectives of integrated reporting are fully met by companies. While South African listed companies are no exception in this regard, it is interesting to note the improvement in the level of their reporting. Part of this improvement is attributed to the King III guidelines (IOD, 2009) and the South African Discussion Paper on Integrated Reporting (SAIRC Discussion Paper, 2011) 
in encouraging companies to make integrated reporting part of their business. In addition, the JSE listing requirements (JSE, 2011) urge listed companies to comply with King III or to provide reasons for failing to do so.

As a new concept, integrated reporting has opened the door for future research. In its Discussion Paper (IIRC Discussion Paper, 2011), the IIRC has voiced its intention to publish an Exposure Draft on integrated reporting in 2012 after it has received comments from various organisations and the public. Future research can therefore take different forms, including exploring the extent to which reporting by South African or international companies will have improved after the Exposure Draft has been published. In addition, researchers can decide to use a variety of research indicators, including the financial performance indicators (which were not used in this study), to test the quality of information presented in the annual reports.

\section{LIST OF REFERENCES}

Accountancy SA, (December 2011). Integrated reporting - the status quo. [Online] Available: http://www.accountancysa.org.za/resources/ShowltemArticle.asp?Article=Integrated+Reporting++ The + Status + Quo\&Articleld $=2344 \&$ lssue $=1111$. (Accessed 2 February 2012).

Adams, C. \& Zutshi, A. (2004). Corporate social responsibility: why business should act responsibly and be accountable. Australian Accounting Review, 14(34), pp. 31-39.

Bhimani, A. (2009). Risk management, corporate governance and management accounting: Emerging interdependencies. Management Accounting Research, 20, pp. 2-5.

Carte, D. (2011). "Integrated" financial reporting. [Online] Available:

http://www.moneyweb.co.za/mw/view/mw/en/page292673?oid=526277\&sn=2009+Detail. (Accessed 2 February 2012).

Companies Act, No.71 of 2008. South Africa.

Doane, D. (2002). Market failure: the case for mandatory social and environmental reporting. New Economics Foundation.

Eccles, R. \& Armbrester, K. (2011). Integrated reporting in the cloud. IESEinsight, Issue 8, First Quarter, 2011.

Global Reporting Initiative (GRI). (2011). Sustainability reporting guidelines. Boston: GRI, Version 3.1.

Gray, R. (2001). Thirty years of social accounting, reporting and auditing: what (if anything) have we learnt? Business Ethics: A European Review.

Hay, M. \& Williamson, P. (1997). Good strategy: the view from below. Long Range Planning, 30(5), pp. 651-664.

International Accounting Standards Board (IASB). (2010). Conceptual framework for financial reporting 2010. Management Commentary 2010: IFRS Practice Statement.

International Integrated Reporting Committee (IIRC) Discussion Paper. (2011). Towards integrated reporting: communicating value in the $21^{\text {st }}$ century.

Institute of Directors in Southern Africa (I0D) (1994). King Report on Governance for South Africa. Institute of Directors in Southern Africa (IOD) (2002). King Report on Governance for South Africa. 
Institute of Directors in Southern Africa (IOD) (2009). King Report on Governance for South Africa. Jensen, M.C. \& Meckling, W.H. (1976). Theory of the firm: managerial behaviour, agency costs and ownership structure. Journal of Financial Economics, 3(4), pp. 305-460.

JSE Limited Listings Requirements (JSE, 2011). Service Issue 14.[Online] Available:

http://www.jse.co.za/How-To-List/Main-Board/Listing-requirements/JSE-listing-requirements.aspx (Accessed 28 September 2011).

Kolk, A. (2005). Sustainability reporting. Journa/ nr.3, najaar 2005.

Labuschagne, C., Brent, A.C. \& Van Erck, R.P.G. (2004). Assessing the sustainability performance of industries. Journal of Cleaner Production. [Online] Available:

http://repository.up.ac.za/bitstream/handle/2263/4325/Labuschagne_Assessing(2005).pdf?seque nce $=1$.

Ligteringen, $\varepsilon$. \& Zadek, S. (2002). The future of corporate responsibility codes, standards and frameworks. Global Reporting Initiative and Accountability.

McCarty, L.S. \& Power, M. (2000). Approaches to developing risk management objectives: an analysis. Environmental Science \& Policy, 3, pp. 311-319.

Nazari, M. (2009). Sustainability reporting using GRI: lessons learned. Environment, Mining.com.

Olsson, R. (2007). In search of opportunity management: is the risk management process enough?

International Journal of Project Management, 25, pp. 745-752

Oxford Advanced Learner's Dictionary. (2000). $6^{\text {th }}$ edition. Oxford: 0xford University Press

Porter, M. (1996). What is strategy? Harvard Business Review, pp. 59-78.

Rossouw, G.J., Van der Walt, A. \& Malan, D.P. (2002). Corporate governance in South Africa. Journal of Business Ethics, 37, pp. 289-302.

Sarens, G., De Beelde, I. \& Everaert, P. (2009). Internal audit: a comfort provider to the audit committee. The British Accounting Review, 41, pp. 90-106.

Shkolnikov, A. and Wilson, A. (2009). From sustainable companies to sustainable economies. Centre for International Private Enterprise, United States Agency for International Development.

South Africa.Info, (January 2011). SA leads way in integrated reporting. [Online] Available: http://www.southafrica.info/news/business/king-260111.htm. (Accessed 5 February 2012).

South African Integrated Reporting Committee (SAIRC) Discussion Paper (2011). Framework for integrated reporting and the integrated report.

Steyn, B. \& de Beer, દ. (2011). The strategic role of public relations in the process of integrated reporting. [Online] Available: http://www.prconversations.com/index.php/2011/11/integratedreporting-and-strategic-public-relations/. Retrieved 2 February 2012.

United Nations Agenda 21 (UN Agenda 21, 1992) [Online] Available: http://www.un.org/esa/dsd/agenda21. (Accessed 24 January 2012).

United Nations Global Compact (UN Global Compact, 2000) [Online] Available: http://www.unglobalcompact.org/,. (Accessed 24 January 2012).

Van Wyk, R., Bowen, P. \& Akintoye, A. (2008). Project risk management practice: the case of a South African utility company. International Journal of Project Management, 26, pp. 149-163. 